Interactive comment on "Effect of Atmospheric Stability on the Wind Resource extrapolating models for large capacity Wind Turbines: A Comparative Analysis of Power Law, Log Law and Deaves and Harris mode" by Pramod Kumar Sharma et al.

\title{
P. SHARMA
}

sharma786pramod@gmail.com

Received and published: 23 May 2018

\section{Dear sir}

With reference to comments on section 3, figures obtained from windPRO can be utilized in other ways. Please find the latest added figures file to the manuscript. 
https://www.wind-energ-sci-discuss.net/wes-2018-16/wes-2018-16-SC1supplement.pdf

WESD

Interactive comment on Wind Energ. Sci. Discuss., https://doi.org/10.5194/wes-2018-16, 2018.

Interactive comment 